\title{
Phase Transitions in the Co-Al-Nb-Mo System
}

\author{
Denis Davydov ${ }^{1,2}$, Nataliya Kazantseva ${ }^{1, *(\mathbb{C}, \text { Nikolai Popov }}{ }^{2}$, Nina Vinogradova ${ }^{1}$ and Igor Ezhov ${ }^{1}$ \\ 1 Institute of Physics of Metals, Ural Branch of Russian Academy of Sciences, 620218 Ekaterinburg, Russia; \\ davidov@imp.uran.ru (D.D.); egorova@imp.uran.ru (N.V.); ezhov@imp.uran.ru (I.E.) \\ 2 Institute of New Materials and Technologies, Ural Federal University, 620002 Ekaterinburg, Russia; \\ n.a.popov@urfu.ru \\ * Correspondence: kazantseva@imp.uran.ru; Tel.: +7-982-632-0529
}

check for

updates

Citation: Davydov, D.; Kazantseva, N.; Popov, N.; Vinogradova, N.; Ezhov, I. Phase Transitions in the Co-Al-Nb-Mo System. Metals 2021, 11, 1887. https://doi.org/10.3390/ met11121887

Academic Editor: Umberto Prisco

Received: 26 October 2021

Accepted: 19 November 2021

Published: 23 November 2021

Publisher's Note: MDPI stays neutral with regard to jurisdictional claims in published maps and institutional affiliations.

\begin{abstract}
Phase transitions in the Co-rich part of the $\mathrm{Co}-\mathrm{Al}-\mathrm{Nb}-\mathrm{Mo}$ phase diagram are studied by energy dispersive spectroscopy (EDS), X-ray analysis, transmission electron microscopy (TEM), and differential scanning calorimetry (DSC) measurements. The obtained results were compared with the results for alloys of the binary $\mathrm{Co}-\mathrm{Al}$ and ternary $\mathrm{Co}-\mathrm{Al}-\mathrm{Nb}$, and $\mathrm{Co}-\mathrm{Al}-\mathrm{Mo}$ systems. Formation of the intermetallic phase with the $\mathrm{L}_{2}$ structure was found in a range of alloys with 10 at.\% Al, 2-9 at. $\% \mathrm{Nb}$, and 3-7 at.\% Mo. Intermetallic compound $\mathrm{Co}_{2} \mathrm{Nb}$, Laves phase with the different chemical composition and crystal structure (C14 and C36) was detected in the $\mathrm{Co}-\mathrm{Al}-\mathrm{Nb}$ and $\mathrm{Co}-\mathrm{Al}-\mathrm{Nb}-\mathrm{Mo}$ samples after vacuum solution treating at $1250{ }^{\circ} \mathrm{C}$ for $30 \mathrm{~h}$.
\end{abstract}

Keywords: heat resistant superalloys; phase transitions; $\mathrm{Co}-\mathrm{Al}-\mathrm{Nb}-\mathrm{Mo} ; \mathrm{L}_{2}$ structure

\section{Introduction}

Cobalt and nickel heat resistant alloys are widely used in industry. To increase the efficiency of gas turbine engines, an increase in the operating temperatures and an increase in the number of revolutions of the turbine are needed. The last ones are limited by the mechanical and physical properties of its heat-resistant parts. The development of new heat resistant alloys used for manufacturing such parts requires knowledge of the phase diagram of multicomponent systems. For a long time, it was believed that carbides are the main hardening phases in cobalt-based alloys [1]. The discovery of an intermetallic phase with an ordered $\mathrm{L}_{2}$ structure in cobalt alloys of the Co-Al-W system initiated the study of new heat resistant cobalt-based intermetallic superalloys and of the possibility of the formation of an intermetallic phase with an $\mathrm{L}_{2}$ structure in other cobalt and nickel systems including multicomponent ones. As is known, the study of phase transformations in multicomponent phase diagrams is associated with great difficulties. Ternary phase diagrams have tried to reduce to a pseudo-binary, while multicomponent ones are reduced to pseudo-ternary phase diagrams. Isothermal sections of the phase multicomponent diagram are usually divided into parts (slices) including the concentration region of interest of the phase diagram. Therefore, it is not always possible to find phase diagrams of a multi-component system.

The intermetallic $\gamma^{\prime}$-phase with the $\mathrm{L}_{2}$ structure was found in several alloys of the $\mathrm{Co}-\mathrm{Al}-\mathrm{Nb}-\mathrm{Mo}$ multicomponent system $[2,3]$. However, there are no phase diagrams or even parts of the phase diagram of this system in the literature. To determine the phase equilibria in the $\mathrm{Co}-\mathrm{Al}-\mathrm{Nb}-\mathrm{Mo}$ system, data on the following three ternary systems: $\mathrm{Co}-\mathrm{Al}-$ $\mathrm{Mo}, \mathrm{Co}-\mathrm{Nb}-\mathrm{Mo}$, and $\mathrm{Co}-\mathrm{Al}-\mathrm{Nb}$ may be used [1,4-7]. The phase analysis in binary phase diagrams Al-Mo [8], Co-Mo [9], Co-Nb [7,9,10], Co-Al [11], Nb-Mo [12], and Nb-Al [7,13] may also be used.

At the same time, according to the literature data, there is no intermetallic compound with an $\mathrm{L}_{2}$ structure in constituent ternary systems such as $\mathrm{Co}-\mathrm{Al}-\mathrm{Nb}[1,4-7], \mathrm{Co}-\mathrm{Al}-$ $\mathrm{Mo}$ [1], or $\mathrm{Co}-\mathrm{Nb}-\mathrm{Mo}$ [4]. Thus, the temperature and concentration regions of the existence of the intermetallic phase with an $\mathrm{L}_{2}$ structure in the $\mathrm{Co}-\mathrm{Al}-\mathrm{Nb}-\mathrm{Mo}$ system are unknown. 
The purpose of this work was the experimental determination of phase transitions in the $\mathrm{Co}-\mathrm{Al}-\mathrm{Nb}-\mathrm{Mo}$ alloys (Co-rich part of the phase diagram).

\section{Materials and Methods}

Electrolytic cobalt (purity no less than $99.98 \mathrm{wt} . \%$ ), molybdenum (purity no less than $99.95 \mathrm{wt. \%}$ ), aluminum (99. $5 \mathrm{wt. \%}$ ), and niobium (99.87 wt.\%) produced by arc melting (purity no less than $99.8 \mathrm{wt}$ \%) were used to prepare the alloys. The alloys were obtained with a vacuum arc furnace, afterward, the ingots were remelted four times with a helium arc furnace. The cast ingots were vacuum solution treated at $1250{ }^{\circ} \mathrm{C}$ for $30 \mathrm{~h}$. The chemical composition of the alloys was defined with a Jeol JSM-6490LV (JEOL Ltd., Tokyo, Japan) scanning electron microscope (SEM) equipped with an Oxford Instruments Inca Energy 350 energy-dispersive spectrometer (NanoAnalysis, Wiesbaden, Germany) for elemental analysis. The microstructure of the samples was investigated with a JEM-200CX (JEOL Ltd., Tokyo, Japan) transmission electron microscope. X-ray diffraction analysis was performed using a DRON-3 X-ray diffractometer (Bourevestnik, JSC, St. Petersburg, Russia) with $\mathrm{Cu} \mathrm{k} \alpha$ radiations. Differential scanning calorimetry (DSC) was performed with an STA 449 C Jupiter synchronous thermal analysis setup (NETZSCH-Gerätebau GmbH, Selb, Germany). DSC measurement accuracy was provided as follows: temperature- $+0.50{ }^{\circ} \mathrm{C}$; enthalpy $-+2 \%$; heat capacity $-+2 \%$; temperature range: room. $+1200^{\circ} \mathrm{C}$; heating $/$ cooling rate of $10^{\circ} \mathrm{C} / \mathrm{min}$; in the chamber medium, an inert gas (argon) was used.

The nominal and measured by energy-dispersive spectrometry (EDS) chemical compositions of the studied alloys are given in Table 1.

Table 1. Chemical composition of the studied alloys, at.\%.

\begin{tabular}{ccccc}
\hline Alloy/Elements & Co & Al & Nb & Mo \\
\hline 1 & Bal. & $10(9.8)$ & - & - \\
2 & Bal. & $10(9.68)$ & - & $5(4.86)$ \\
3 & Bal. & $10(8.92)$ & $2(1.9)$ & - \\
4 & Bal. & $10(9.86)$ & $2(2.08)$ & $5(4.77)$ \\
5 & Bal. & $10(8.86)$ & $3(3.14)$ & $7(7.5)$ \\
6 & Bal. & $10(9.46)$ & $9(9)$ & $3(2.9)$ \\
7 & Bal. & $10(8.9)$ & $5(4.7)$ & $7(6.5)$ \\
8 & Bal. & $10(9.1)$ & $5(5.2)$ \\
\hline
\end{tabular}

\section{Results and Discussion}

According to the literature, the phase composition of the Co-10Al-2Nb-5Mo alloy differs significantly among different researchers. In addition to the solid solution based on cobalt $(\gamma-\mathrm{Co})$ in this alloy, the presence of six different intermetallic phases has been reported in different works (Table 2). Makineni et al. [2] found the needle precipitations in the $\mathrm{Co}-10 \mathrm{Al}-2 \mathrm{Nb}-5 \mathrm{Mo}$ alloy after aging at $800^{\circ} \mathrm{C}$. According to the EDS and TEM study provided in [2], it was suggested that these precipitations belong to the intermetallic compound $\mathrm{Co}_{3} \mathrm{Mo}$ with the hexagonal structure $\mathrm{D}_{19}$. This intermetallic compound exists in the binary Co-Mo and ternary $\mathrm{Co}-\mathrm{Nb}-\mathrm{Mo}$ and $\mathrm{Co}-\mathrm{Al}-\mathrm{Mo}$ phase diagrams $[1,4,9]$. In the binary $\mathrm{Co}-\mathrm{Mo}$ phase diagram, the $\mathrm{Co}_{3} \mathrm{Mo}$ intermetallic compound with the $\mathrm{D0}_{19}$ crystal structure had a narrow homogeneity range and is shown as a line compound model with $\mathrm{Co}_{3} \mathrm{Mo}$ stoichiometry [9]. In the binary Co-Mo phase diagram, the intermetallic compound $\mathrm{Co}_{3} \mathrm{Mo}$ was formed by peritectoid reaction at $1025^{\circ} \mathrm{C}$. A solid solution based on $\varepsilon$-Co (hcp) was formed by the peritectoid reaction $\alpha-\mathrm{Co}+\mathrm{Co}_{3} \mathrm{Mo}$ at a temperature of $\approx 700{ }^{\circ} \mathrm{C}$ [14]. In the ternary $\mathrm{Co}-\mathrm{Nb}-\mathrm{Mo}$ system at $1000{ }^{\circ} \mathrm{C}$, the $\mathrm{Co}_{3} \mathrm{Mo}$ intermetallic compound can contain up to 6.2 at.\% of niobium [2,7]. Makineni et al. [15] reported on the formation of intermetallic compounds $\mathrm{Co}_{3}(\mathrm{Mo}, \mathrm{Nb})$ with the D019 structure and CoAl with the B2 structure in the Co-10 at. \% Al-5 at.\% Mo-2 at.\% Nb alloy after annealing for $35 \mathrm{~h}$ at $800{ }^{\circ} \mathrm{C}$. These phases, as suggested, were formed due to the decomposition of the ordered $\gamma^{\prime}$-phase 
$\left(\mathrm{Co}_{3}(\mathrm{Al}, \mathrm{Nb}, \mathrm{Mo})\right)$. On the other hand, in the same alloy $\mathrm{Co}-10 \mathrm{Al}-2 \mathrm{Nb}-5 \mathrm{Mo}$, the presence of the $\mathrm{Co}_{2} \mathrm{Nb}$ Laves phase was reported by Damian Migas et al. [16] (Table 2).

Table 2. Crystal structures of the reported phases in the $\mathrm{Co}-\mathrm{Al}-\mathrm{Nb}-\mathrm{Mo}$ system.

\begin{tabular}{ccc}
\hline Phase & Structural Type & References \\
\hline $\mathrm{MoCo}_{3}$ & $\mathrm{D}_{19}, \mathrm{P}_{3} / \mathrm{mmc}, 194, \mathrm{Mg}_{3} \mathrm{Cd}$ & {$[3,15]$} \\
$\alpha-(\mathrm{Co})$ & $\mathrm{A} 1, \mathrm{Fm} \overline{3} \mathrm{~m}, 225, \mathrm{Cu}$ & {$[2,3,15,17,18]$} \\
$\alpha-\mathrm{Co}_{2} \mathrm{Nb}$ & $\mathrm{C} 36, \mathrm{P} 6_{3} / \mathrm{mmc}, 194, \mathrm{MgNi}{ }_{2}$ & {$[16]$} \\
$\beta-\mathrm{Co}_{2} \mathrm{Nb}$ & $\mathrm{C} 14, \mathrm{P} 6_{3} / \mathrm{mmc}, 194, \mathrm{MgZn} \mathrm{m}_{2}$ & {$[17,18]$} \\
$\gamma-\mathrm{Co}_{2} \mathrm{Nb}$ & $\mathrm{C} 15, \mathrm{Fd} \overline{3} \mathrm{~m}, 227, \mathrm{Cu}_{2} \mathrm{Mg}$ & {$[3]$} \\
$\mathrm{CoAl}$ & $\mathrm{B} 2, \mathrm{Pm} \overline{3} \mathrm{~m}, 221, \mathrm{CsCl}$ & {$[15]$} \\
$\mathrm{Co}_{3}(\mathrm{Al}, \mathrm{Nb}, \mathrm{Mo})$ & $\mathrm{L} 1_{2}, \mathrm{Pm} \overline{3} \mathrm{~m}, 221, \mathrm{Cu}_{3} \mathrm{Au}$ & {$[2,3,15,17,18]$} \\
\hline
\end{tabular}

In order to accurately establish the crystal structure of intermetallic phases in the studied quaternary alloys of the $\mathrm{Co}-\mathrm{Al}-\mathrm{Nb}-\mathrm{Mo}$ system, first, we conducted a study of binary $(\mathrm{Co}-10 \mathrm{Al})$ and ternary alloys $(\mathrm{Co}-10 \mathrm{Al}-\mathrm{X} \% \mathrm{Nb}$ and $\mathrm{Co}-10 \mathrm{Al}-\mathrm{Y} \% \mathrm{Mo})$. In our study, the phase composition of the studied $\mathrm{Co}-10$ at.\%Al alloy should correspond to the binary $\mathrm{Co}-\mathrm{Al}$ phase diagram $[11,19]$. The phase states of the studied ternary $\mathrm{Co}-10 \mathrm{Al}-5 \mathrm{Mo}$ and $\mathrm{Co}-10 \mathrm{Al}-2 \mathrm{Nb}$ alloys should correspond to the ternary $\mathrm{Co}-\mathrm{Al}-\mathrm{Mo}$ and $\mathrm{Co}-\mathrm{Al}-\mathrm{Nb}$ phase diagrams [1,5-7]. The results of the differential scanning calorimetry (DSC) of the studied alloys are presented in Table 3. Some of the DSC thermograms are shown in Figure 1.

Table 3. Results of the differential scanning calorimetry (DSC) of the studied alloys.

\begin{tabular}{|c|c|c|c|c|c|c|c|c|c|c|}
\hline \multirow{3}{*}{$\begin{array}{c}\text { Alloy } \\
1\end{array}$} & \multicolumn{4}{|c|}{ Nominal Composition, at.\% } & \multirow{2}{*}{\multicolumn{4}{|c|}{$\begin{array}{l}\text { The Temperature of the Phase } \\
\text { Transitions, }{ }^{\circ} \mathrm{C} \text { (Heating) }\end{array}$}} & \multirow{2}{*}{\multicolumn{2}{|c|}{$\begin{array}{l}\text { The Temperature of the Phase } \\
\text { Transitions, }{ }^{\circ} \mathrm{C} \text { (Cooling) }\end{array}$}} \\
\hline & \multirow{2}{*}{$\begin{array}{c}\text { Co } \\
\text { base }\end{array}$} & \multirow{2}{*}{$\begin{array}{l}\text { Al } \\
10\end{array}$} & \multirow{2}{*}{$\mathrm{Nb}$} & \multirow{2}{*}{ Mo } & & & & & & \\
\hline & & & & & 256 & 820 & - & - & 200 & 800 \\
\hline 2 & base & 10 & - & 5 & - & 696 & 757 & - & 626 & 682 \\
\hline 3 & base & 10 & 2 & - & - & 742 & - & - & - & 687 \\
\hline 4 & base & 10 & 2 & 5 & - & 707 & 867 & - & 650 & 847 \\
\hline 5 & base & 10 & 3 & 7 & - & 711 & 916 & - & - & 911 \\
\hline 6 & base & 10 & 4 & 3 & - & 720 & 914 & - & 640 & 880 \\
\hline 7 & base & 10 & 9 & 7 & 390 & 707 & 950 & & - & 896 \\
\hline 8 & base & 10 & 5 & 5 & 397 & 632 & 721 & 942 & 650 & 917 \\
\hline
\end{tabular}

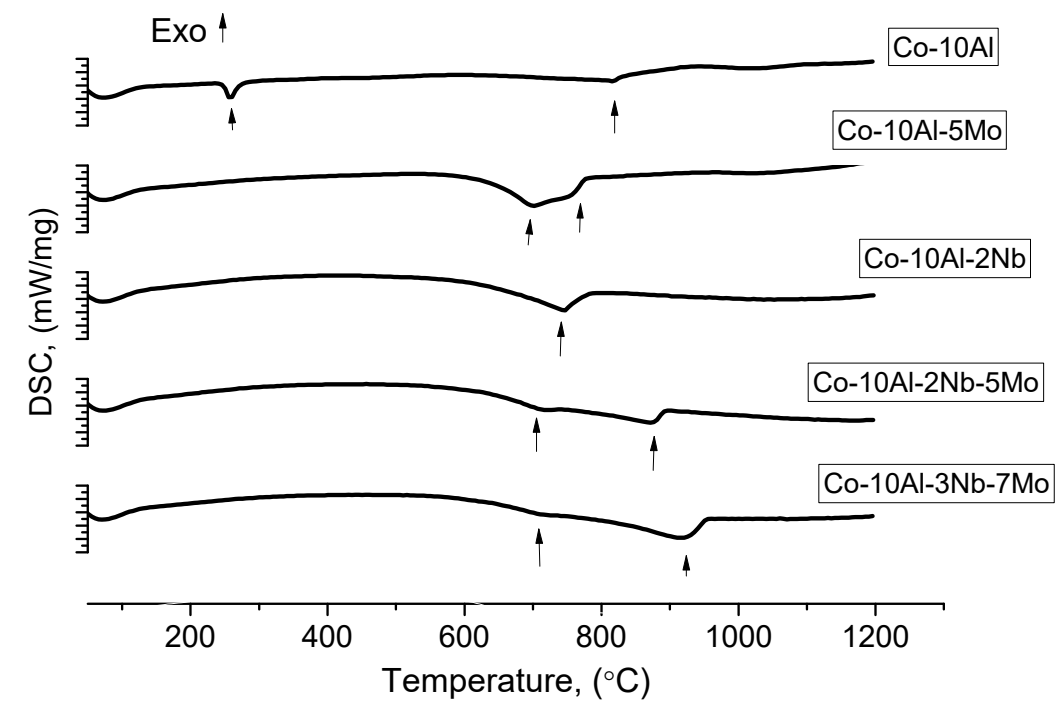

Figure 1. DSC thermograms of the studied alloys.

DSC curve of the homogenized Co-10Al alloy showed two minimums in the temperature range up to $1200{ }^{\circ} \mathrm{C}$. According to the Co-Al phase diagram [11,19], the DSC minimum at $\approx 256^{\circ} \mathrm{C}$ may correspond to the $\alpha+\varepsilon \rightarrow B 2+\alpha$ phase transition, and $820{ }^{\circ} \mathrm{C}$ 
is the temperature at the beginning of the $B 2+\alpha \rightarrow \alpha$ phase transition. Thus, at the homogenization temperature of $1250^{\circ} \mathrm{C}$, this alloy was in a single-phase state ( $\alpha$-cobalt). The number of phase transitions in the sample was the same both under heating and cooling (Table 3). Under cooling, the DSC maxima are normally shifted toward lower temperatures.

The number of DSC anomalies in the ternary alloy samples was the same both under heating and cooling. Two minimums were observed in the DSC curve of the Co-10Al$5 \mathrm{Mo}$ alloy under heating (Table 3). According to the Co-Al-Mo phase diagram [1], these minimums may be associated with $\gamma+\mathrm{Co}_{3} \mathrm{Mo} \rightarrow \gamma$ and $\gamma \rightarrow \gamma+\mathrm{B} 2$ phase transitions. At the homogenization temperature of $1250{ }^{\circ} \mathrm{C}$, this alloy was in a two-phase $\gamma+\mathrm{B} 2$ state. According to the pseudo-binary $\mathrm{Co}-10$ at.\%Al- $\mathrm{Nb}$ phase diagram reported in $\mathrm{He}$ et al. [7], at the homogenization temperature of $1250^{\circ} \mathrm{C}$, the $\mathrm{Co}-10 \mathrm{Al}-2 \mathrm{Nb}$ alloy was in a single-phase state ( $\gamma$-phase). It should be pointed out that the FCC Co-solid solution in the cobalt binary phase diagram is named the $\alpha$-phase, and in the ternary phase diagram, the same phase is named the $\gamma$-phase. The DSC curve of the Co-10Al-2Nb alloy showed one anomaly (Table 3); according to the equilibrium phase diagram $\mathrm{Co}-\mathrm{Al}-\mathrm{Nb}$ [5-7], this temperature anomaly can be considered as a $\mathrm{B} 2+\gamma \rightarrow \mathrm{B} 2+\gamma+\alpha-\mathrm{Co}_{2} \mathrm{Nb}$ (C36) phase transition.

DSC curves in the heating regime of the alloys $\mathrm{Co}-10 \mathrm{Al}-2 \mathrm{Nb}-5 \mathrm{Mo}, \mathrm{Co}-10 \mathrm{Al}-3 \mathrm{Nb}-7 \mathrm{Mo}$, and $\mathrm{Co}-10 \mathrm{Al}-4 \mathrm{Nb}-3 \mathrm{Mo}$ showed two anomalies (Table 3). According to Makineni et al. [2], the phase composition of the $\mathrm{Co}-10 \mathrm{Al}-2 \mathrm{Nb}-5 \mathrm{Mo}$ alloy should contain the $\gamma^{\prime}$-phase ( $\mathrm{L1}_{2}$ structure) with the solvus temperature of about $866^{\circ} \mathrm{C}$. Thus, the second anomaly in the DSC curves of the studied Co-10Al- $3 \mathrm{Nb}-7 \mathrm{Mo}, \mathrm{Co}-10 \mathrm{Al}-2 \mathrm{Nb}-5 \mathrm{Mo}$, and $\mathrm{Co}-10 \mathrm{Al}-4 \mathrm{Nb}-$ 3Mo alloys is the $\gamma^{\prime}$-solvus temperature, which is associated with the $\gamma+\gamma^{\prime} \rightarrow \gamma$ phase transition. The first anomaly in the DCS curves of these alloys may be associated with the phase transition such as $\gamma+\gamma^{\prime}+\mathrm{Co}_{2} \mathrm{Nb}\left(\right.$ or $\left.\mathrm{Co}_{3} \mathrm{Mo}\right) \rightarrow \gamma+\gamma^{\prime}$.

With an increase in the total content of alloying elements in the alloy, the number of anomalies in the DSC curves increases. It was observed that after heating up to $1200^{\circ} \mathrm{C}$, the Co-10Al-9Nb-7Mo alloy sample melted. Thus, the alloy with this chemical composition enters the melting zone under heating to $1200^{\circ} \mathrm{C}$. The anomalies in DSC curves of this alloy may be associated with phase transitions such as $\mathrm{B} 2+\gamma+\gamma^{\prime}+\mathrm{Co}_{2} \mathrm{Nb}$ (or $\left.\mathrm{Co}_{3} \mathrm{Mo}\right) \rightarrow \gamma+$ $\gamma^{\prime}+\mathrm{Co}_{2} \mathrm{Nb}\left(\right.$ or $\left.\mathrm{Co}_{3} \mathrm{Mo}\right), \gamma+\gamma^{\prime}+\mathrm{Co}_{2} \mathrm{Nb}\left(\right.$ or $\left.\mathrm{Co}_{3} \mathrm{Mo}\right) \rightarrow \gamma+\gamma^{\prime}, \gamma+\gamma^{\prime} \rightarrow \gamma+\mathrm{L}$. The absence of the transitions to the DSC curves upon cooling the alloy may mean that some of the phases were formed at a high temperature and remained in the alloy after cooling. The DSC curves of the $\mathrm{Co}-10 \mathrm{Al}-5 \mathrm{Nb}-5 \mathrm{Mo}$ alloy sample showed four anomalies on heating and only two on cooling. In comparison with $\mathrm{Co}-10 \mathrm{Al}-9 \mathrm{Nb}-7 \mathrm{Mo}$ alloy, the addition temperature DSC anomaly in this alloy at $632{ }^{\circ} \mathrm{C}$ may be associated with the polymorph transition, for example, such a transition was observed in Laves phases.

In the binary $\mathrm{Co}-\mathrm{Nb}$ system, Laves phases with composition $\mathrm{AB}_{2}$ differed by the particular stacking of the same four-layered structural units: $\mathrm{C} 15$ (space group Fd-3m, $\mathrm{MgCu}_{2}$ structure type), and C14 (space group $\mathrm{P}_{3} / \mathrm{mmc}, \mathrm{MgZn}_{2}$ structural type). C36 Laves phase (space group $\mathrm{P}_{3} / \mathrm{mmc}, \mathrm{MgNi}_{2}$ structure type) also showed a hexagonal crystal structure [20]. In the $\mathrm{Co}-\mathrm{Nb}$ system, $\mathrm{C} 14, \mathrm{C} 15$, and C36 polytypes formed with increasing Co content in the sequence $\mathrm{C} 14, \mathrm{C} 15$, and $\mathrm{C} 36$ and named as $\alpha-\mathrm{Co}_{2} \mathrm{Nb}(\mathrm{C} 36)$, $\beta-\mathrm{Co}_{2} \mathrm{Nb}(\mathrm{C} 14)$, and $\gamma-\mathrm{Co}_{2} \mathrm{Nb}$ (C15) [6]. C14 and C36 are high temperature phases, but can be retained by quenching [20]. Transition from Laves phase $\mathrm{C} 14(2 \mathrm{H})$ to $\mathrm{C} 36(4 \mathrm{H})$ may be described as layer-stacking irregularities [21]. In a ternary $\mathrm{Co}-\mathrm{Al}-\mathrm{Nb}$ system, the Laves phase C36 is the stable phase. The $\mathrm{Nb}$ content of the C36 Laves phase is always significantly below the stoichiometric value of 33.3 at.\%, ranging from about 24 to $28-29$ at.\%. In some of the literature, $\alpha-\mathrm{Co}_{2} \mathrm{Nb}(\mathrm{C} 36)$ is named $\mathrm{Co}_{3} \mathrm{Nb}$ according to strong off-stoichiometric chemical composition [10]. The $\mathrm{Al}$ content of the $\mathrm{C} 36$ phase in the ternary $\mathrm{Co}-\mathrm{Al}-\mathrm{Nb}$ alloys was found to be about 6 at.\%; a maximum 8.4 at.\% $\mathrm{Al}$ in the $\mathrm{C} 36$ Laves phase was found as reported in Dovbenko et al. [5] in the alloys after heat treatment at $1250^{\circ} \mathrm{C}$. With increasing $\mathrm{Nb}$ content in the alloy, the transition was found across the phase boundaries from C36 to $\mathrm{C} 15$ and from $\mathrm{C} 15$ to $\mathrm{C} 14$ [5]. In the Co-10.1Al-20.1Nb alloy, C36 formed peritectically by the reaction $\mathrm{L}+\mathrm{C} 15 \rightarrow \mathrm{C} 36$ [22]. 
To confirm the assumptions of phase transitions and anomalies related to them on the DSC curves of the studied alloys, microscopic studies were carried out. Figures 2 and 3 present the microstructure images of the studied alloys taken with scanning electron microscopy (SEM). Results of the elemental analysis taken from the SEM images are presented in Table 4.

Table 4. Chemical composition of the different phases in the studied alloys according to the SEM results.

\begin{tabular}{|c|c|c|c|c|c|c|c|c|c|}
\hline \multirow{2}{*}{ Alloy No. } & \multicolumn{4}{|c|}{ Nominal Composition, at. $\%$} & \multirow[t]{2}{*}{ Phase Composition of the Alloys } & \multicolumn{4}{|c|}{$\begin{array}{c}\text { Concentration of the Elements in the } \\
\text { Alloy Phases, at. } \%\end{array}$} \\
\hline & Co & Al & $\mathrm{Nb}$ & Mo & & Co & Al & $\mathrm{Nb}$ & Mo \\
\hline 1 & base & 10 & - & - & $\varepsilon_{\mathrm{Co}}+\alpha_{\mathrm{Co}}$ & 91.57 & 8.43 & - & - \\
\hline 2 & base & 10 & - & 5 & $\Gamma+\mathrm{Co}_{3} \mathrm{Mo}\left(\mathrm{DO}_{19}\right)$ & 86.42 & 8.94 & - & 4.64 \\
\hline 3 & base & 10 & 2 & - & $\begin{array}{c}\gamma(+\mathrm{B} 2) \\
\alpha-\mathrm{Co}_{2} \mathrm{Nb}(\mathrm{C} 36)\end{array}$ & $\begin{array}{l}88.75 \\
85.34\end{array}$ & $\begin{array}{l}9.34 \\
8.74\end{array}$ & $\begin{array}{l}1.91 \\
5.92\end{array}$ & - \\
\hline 4 & base & 10 & 2 & 5 & $\begin{array}{c}\gamma+\gamma^{\prime} \\
\alpha-\mathrm{Co}_{2} \mathrm{Nb}(\mathrm{C} 36)\left(\text { or } \mathrm{Co}_{3} \mathrm{Mo} ?\right)\end{array}$ & $\begin{array}{l}84.33 \\
80.04\end{array}$ & $\begin{array}{l}9.03 \\
7.99\end{array}$ & $\begin{array}{l}1.95 \\
6.01\end{array}$ & $\begin{array}{l}4.69 \\
5.96\end{array}$ \\
\hline 5 & base & 10 & 3 & 7 & $\begin{array}{c}\gamma / \gamma^{\prime} \\
\beta-\mathrm{Co}_{2} \mathrm{Nb}(\mathrm{C} 14) \\
\gamma / \gamma^{\prime}\end{array}$ & $\begin{array}{c}77.8 \\
63.2 \\
81.73\end{array}$ & $\begin{array}{c}7.8 \\
4.9 \\
9.54\end{array}$ & $\begin{array}{c}4.3 \\
15.9 \\
3.66\end{array}$ & $\begin{array}{l}10.1 \\
15.9 \\
5.07\end{array}$ \\
\hline 6 & base & 10 & 4 & 3 & $\begin{array}{c}\beta-\mathrm{Co}_{2} \mathrm{Nb}(\mathrm{C} 14) \\
\alpha-\mathrm{Co}_{2} \mathrm{Nb}(\mathrm{C} 36) \\
\gamma / \gamma^{\prime}\end{array}$ & $\begin{array}{l}70.15 \\
75.82 \\
85.82\end{array}$ & $\begin{array}{l}4.40 \\
6.79 \\
8.86\end{array}$ & $\begin{array}{c}17.73 \\
11.09 \\
1.91\end{array}$ & $\begin{array}{l}7.72 \\
6.30 \\
3.41\end{array}$ \\
\hline 7 & base & 10 & 9 & 7 & $\begin{array}{c}\mathrm{B} 2 \\
\alpha-\mathrm{Co}_{2} \mathrm{Nb}(\mathrm{C} 14) \\
\gamma / \gamma^{\prime}\end{array}$ & $\begin{array}{l}72.47 \\
72.39 \\
84.32\end{array}$ & $\begin{array}{l}22.74 \\
3.81 \\
9.21\end{array}$ & $\begin{array}{c}3.18 \\
17.68 \\
4.05\end{array}$ & $\begin{array}{l}1.62 \\
6.12 \\
2.43\end{array}$ \\
\hline 8 & base & 10 & 5 & 5 & $\begin{array}{l}\beta-\mathrm{Co}_{2} \mathrm{Nb}(\mathrm{C} 14) \\
\alpha-\mathrm{Co}_{2} \mathrm{Nb}(\mathrm{C} 36)\end{array}$ & $\begin{array}{l}72.34 \\
76.69\end{array}$ & $\begin{array}{l}3.86 \\
6.06\end{array}$ & $\begin{array}{l}20.18 \\
14.35\end{array}$ & $\begin{array}{l}3.61 \\
2.95\end{array}$ \\
\hline
\end{tabular}
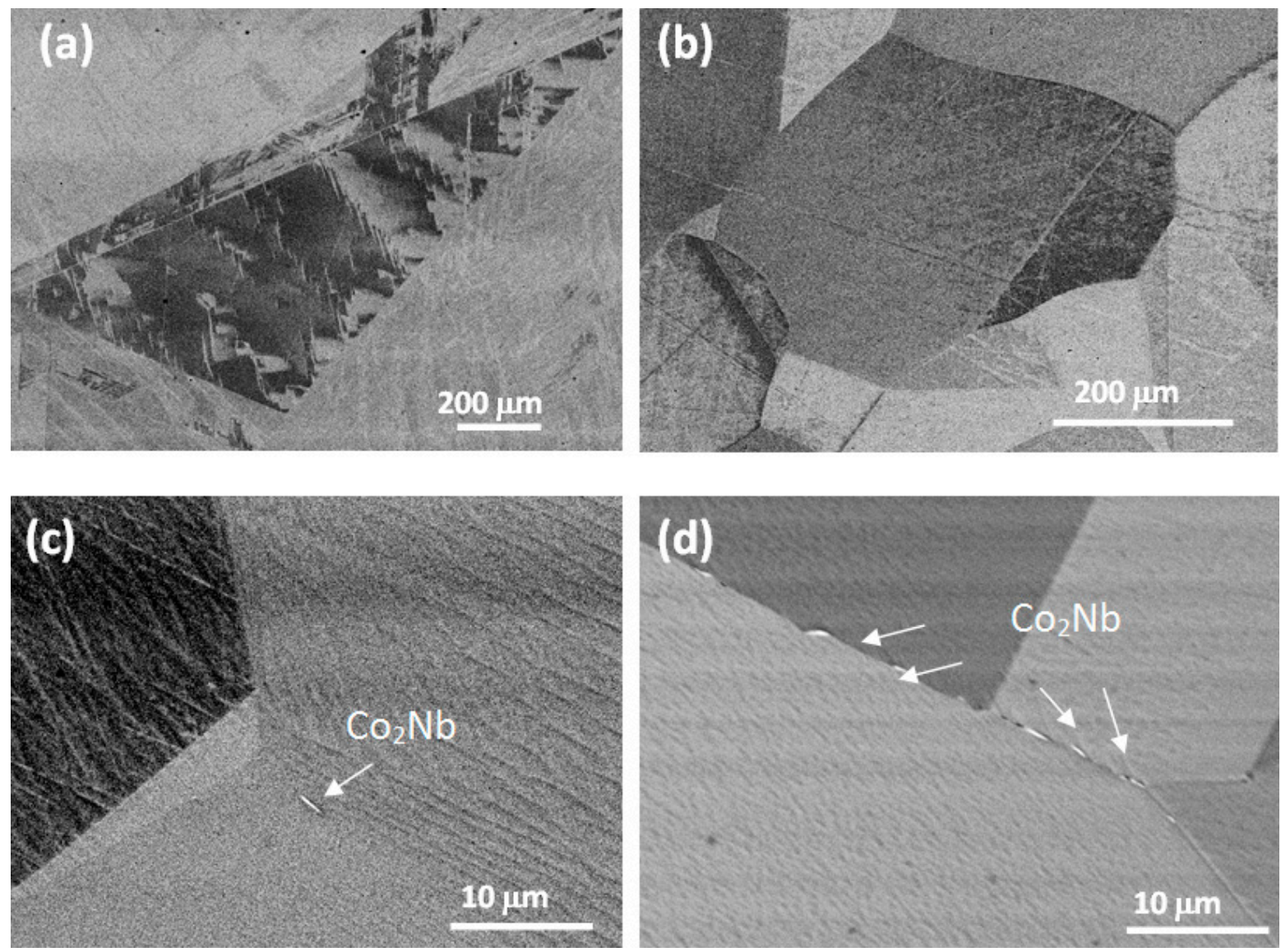

Figure 2. Microstructure of the studied alloys, SEM images: (a) Co-10Al; (b) Co-10Al-5Mo; (c) Co-10Al-2Nb; (d) Co-10Al$2 \mathrm{Nb}-5 \mathrm{Mo}$. 

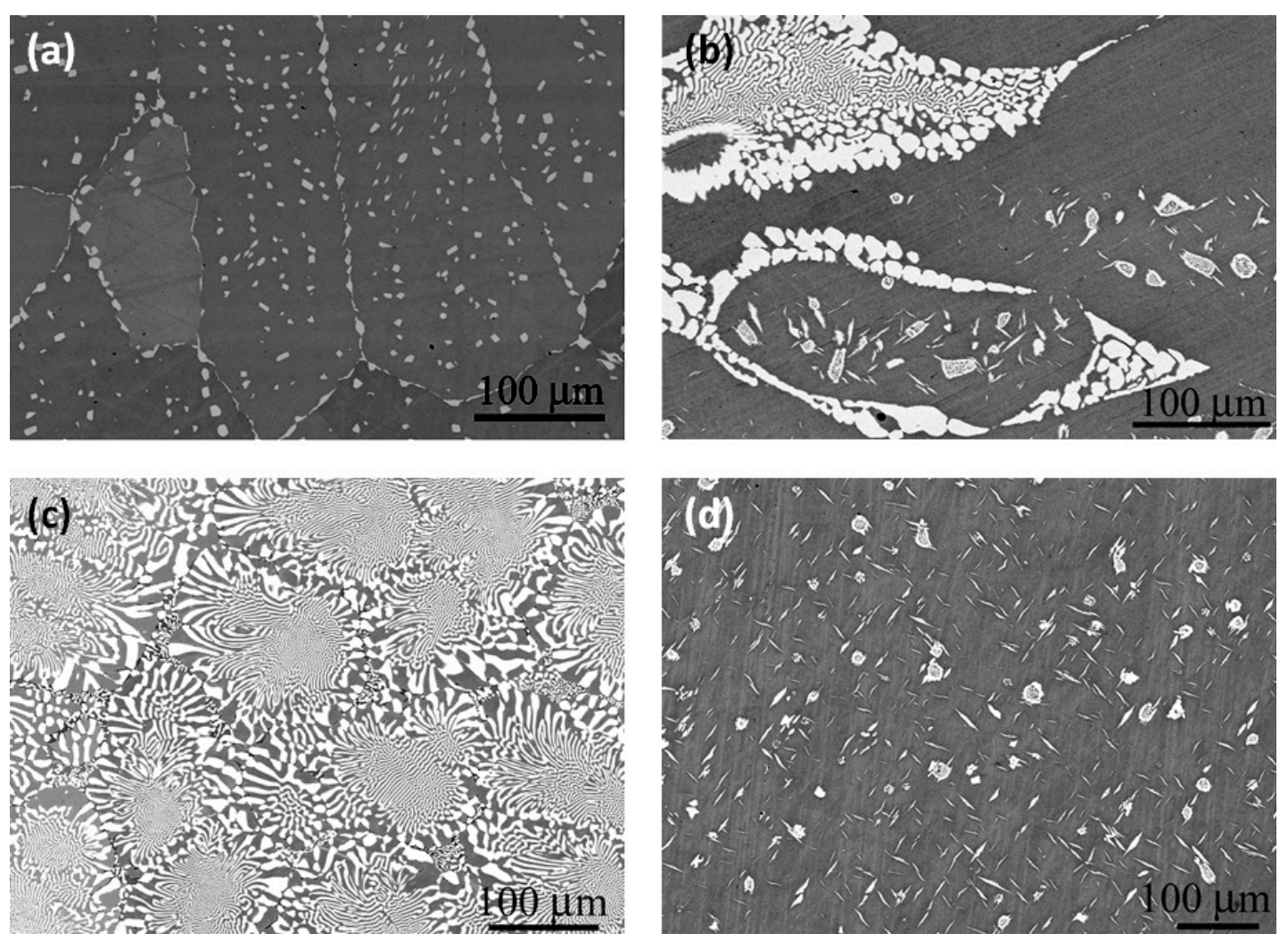

Figure 3. Microstructure of the studied alloys, SEM images: (a) Co-10Al-3Nb-7Mo; (b) Co-10Al-4Nb-3Mo; (c) Co-10Al$9 \mathrm{Nb}-7 \mathrm{Mo} ;$ (d) Co-10Al-5Nb-5Mo.

Martensitic structure of the $\varepsilon$-phase was observed in the Co-10Al alloy (Figure 2a). When studying the Co-10Al-5Mo samples, we did not find the precipitations of the $\mathrm{Co}_{3} \mathrm{Mo}$ intermetallic compound, probably because these precipitations were very small to observe by SEM (Figure 2b). The structure of the $\mathrm{Co}-10 \mathrm{Al}-2 \mathrm{Nb}$ alloy is presented in Figure $3 \mathrm{c}$, where the precipitations of the $\alpha-\mathrm{Co}_{2} \mathrm{Nb}$ (C36) intermetallic compound formed as thin white needles on the grain boundaries. We did not observe $\mathrm{B} 2$ regions enriched with aluminum in SEM images, however, one could be seen in Figure 2c, where the inner structure of the grain is not uniform as it consists of two phases $(\gamma+\mathrm{B} 2)$. In the Co-10Al-2Nb-5Mo alloy (Figure 2d), we also found needle precipitations at the grain boundaries that looked the same as the ones in the Co-10Al-2Nb alloy. According to the results of the chemical analysis (EDS), these precipitates can be associated with both an intermetallic compound $\mathrm{Co}_{3} \mathrm{Mo}$ or with $\mathrm{Co}_{2} \mathrm{Nb}$. Both of these intermetallic phases had a hexagonal crystal lattice in the form of thin needle-like (lamellar) precipitates. The same shape of the phase precipitations was observed in the $\mathrm{Co}-10 \mathrm{Al}-2 \mathrm{Nb}-5 \mathrm{Mo}$ alloy as reported in Makineni et al. [2]. Chemical analysis of these precipitations showed an equal content of molybdenum and niobium (Table 4). It can be seen that the composition of the intermetallic phase was close to $\mathrm{AB}_{3}$ rather than $\mathrm{AB}_{2}$. According to Makineni et al. [15], plate-like $\mathrm{Co}_{3}$ Mo precipitations with the chemical composition $\mathrm{Co}=75.2$ at. $\%, \mathrm{Nb}=11.8$ at $\%, \mathrm{Mo}=12.3$ at. $\%$, and $\mathrm{Al}=0.7$ at. $\%$ and suggested $\mathrm{DO}_{19}$ crystal structure were observed in the $\mathrm{Co}-10 \mathrm{Al}-5 \mathrm{Mo}-2 \mathrm{Nb}$ alloy. In the $\mathrm{Co}-\mathrm{Nb}$ system, a strong deviation from the stoichiometric composition was observed for the Laves phase $\mathrm{C} 36$, where the chemical composition was close to the formula $\mathrm{AB}_{3}$. In appearance, intermetallic precipitates in the $\mathrm{Co}-10 \mathrm{Al}-2 \mathrm{Nb}-5 \mathrm{Mo}$ alloy were similar to those observed in the $\mathrm{Co}-10 \mathrm{Al}-2 \mathrm{Nb}$ alloy (Figure 2c).

Intermetallic precipitates with a completely different morphology can be seen in alloys with an increase in the content of molybdenum and niobium (Figure 3). In the Co-10Al$3 \mathrm{Nb}-7 \mathrm{Mo}$, the precipitations had a rectangular shape (Figure $3 \mathrm{a}$ ). The aluminum content was found to be 4.9 at. $\%$, and the contents of molybdenum and niobium were 15.9 at. $\%$ and 
equal to each other (Table 4). Thus, the chemical composition of intermetallic precipitates was close to the formula $\mathrm{AB}_{2}$ (i.e., these precipitates are most likely associated with the Laves phase $\mathrm{Co}_{2} \mathrm{Nb}(\mathrm{C} 14)$ ). Needle-like precipitates with a chemical composition close to $\mathrm{AB}_{3}$ and round (or close to rectangular) particles with a composition close to $\mathrm{AB}_{2}$ could also be seen in alloys Co-10Al-4Nb-3Mo and Co-10Al-5Nb-5Mo (Figure 3b,d). These particles also differed in their niobium content. Round particles contain more niobium than needle particles (Table 4). In general, these precipitations look like typical peritectic particles. In a binary $\mathrm{Co}-\mathrm{Nb}$ system, the $\mathrm{Co}_{2} \mathrm{Nb}$ Laves phase (C36) forms by peritectic reaction from liquid metal and the $\mathrm{Co}_{2} \mathrm{Nb}$ phase $(\mathrm{C} 15)$ [20]. In a ternary Co-Al-Nb system, the Laves phase C36 is the stable phase. According to the EDS results (Table 4), the platelike participations with a higher content of aluminum and smaller content of niobium than those of the rounded participations can be considered as secondary peritectic particles.

Lamellar eutectic structure could be observed in the Co-10Al-7Mo-9Nb alloy (Figure 3c). According to EDS analysis (Table 4), aluminum enriched regions (CoAl, B2 phase) were found on the grain boundaries. Intermetallic phase CoAl with B2 crystal ordered structure forms in ternary Co-Al-Nb system. This phase is enriched with aluminum and cobalt and has a large homogeneous region from 30 up to 50 at.\% Al and with a solubility for $\mathrm{Nb}$ up to 9.2 at.\% [5]. The CoAl phase (B2) was also observed in the Co-10Al-2Nb-5Mo alloy [15]. The regions enriched in niobium, the chemical composition of which was close to the formula $\mathrm{AB}_{2}$, were also found at grain boundaries of the $\mathrm{Co}-10 \mathrm{Al}-7 \mathrm{Mo}-9 \mathrm{Nb}$ alloy (Figure $3 \mathrm{c}$ ). Thus, these intermetallic regions can be associated with the $\mathrm{Co}_{2} \mathrm{Nb}$ Laves phase (C14). The different contents of molybdenum in this phase in different alloys (Table 4) is probably associated with the entry of the chemical composition of the alloy into the zone of polymorphic transformations in the $\mathrm{Co}_{2} \mathrm{Nb}$ Laves phases $(\mathrm{C} 15 \rightarrow \mathrm{C} 36 \rightarrow \mathrm{C} 14)$, as reported in Stein at al. [23]. These detected interesting phase transitions require additional research and separate work.

The transmission electron microscope (TEM) images revealed the presence of the diffraction reflexes of the ordered $\gamma^{\prime}$ phase $\left(\mathrm{L1}_{2}\right)$ in the SAED patterns of the studied alloys (Figure 4). The dark-field images taken with the $\gamma^{\prime}$-phase reflexes showed the cuboidal structure in all studied alloys of the $\mathrm{Co}-\mathrm{Al}-\mathrm{Nb}-\mathrm{Mo}$ system. The $\Gamma^{\prime}$-phase, intermetallic compound $\mathrm{Co}_{3}(\mathrm{Al}, \mathrm{Mo}, \mathrm{Nb})$ with the $\mathrm{L}_{2}$ ordered structure and cuboidal morphology was observed in Co-Al-Nb-Mo alloys as reported in Makineni et al. [2], Tomaszewska et al. [3], Makineni et al. [15], and Davydov et al. [17,18]. As reported in Makineni et al. [2], the chemical composition of this phase was defined as $\mathrm{Co}-10.6 \mathrm{Al}-8.7 \mathrm{Mo}-4.8 \mathrm{Nb}$.

We also did not find the presence of this phase in ternary $\mathrm{Co}-\mathrm{Al}-\mathrm{Nb}$ or $\mathrm{Co}-\mathrm{Al}-\mathrm{Mo}$ alloys. Thus, the need for additions of the fourth component (niobium or molybdenum) for the formation of an ordered gamma prime phase $\left(\gamma^{\prime}\right.$-phase, $\left.\mathrm{L1}_{2}\right)$ is shown.

Figure 4 shows the dark-field images taken with the diffraction reflex of the $\mathrm{Co}_{2} \mathrm{Nb}$ intermetallic compound (Laves phase, C36) and $\mathrm{Co}_{3} \mathrm{Mo}$ intermetallic compound. It can be seen from the TEM images that both of these intermetallic compounds have a needle-like structure and a HCP crystal lattice. The crystal parameters of the $\mathrm{Co}_{2} \mathrm{Nb}$ (Laves phases) and $\mathrm{Co}_{3} \mathrm{Mo}$ intermetallic compounds according to [23-25] may be considered as follows: $\alpha-\mathrm{Co}_{2} \mathrm{Nb}(\mathrm{C} 36), \mathrm{a}=0.477 \mathrm{~nm}, \mathrm{c}=1.559 \mathrm{~nm} ; \beta-\mathrm{Co}_{2} \mathrm{Nb}(\mathrm{C} 14), \mathrm{a}=0.4782 \mathrm{~nm}, \mathrm{c}=0.7765 \mathrm{~nm}$; $\mathrm{Co}_{3} \mathrm{Mo}\left(\mathrm{D0}_{19}\right), \mathrm{a}=0.5112 \mathrm{~nm}, \mathrm{c}=0.4089 \mathrm{~nm}$. All of these phases had hexagonal crystal lattices, but the differences between them were determined by the structural factor, which is associated with element ordering that forbids the appearances of some of the diffraction reflexes. Thus, the SAED patterns in TEM images of these intermetallic compounds will differ not only in distance from the central spot to the diffraction reflex and intensity of the reflex as well as whether this reflex is permitted by the structural factors of the ordered phases. It should also be taken into account that, in contrast to cubic crystal crystals, crystals with a hexagonal crystal lattice can have forbidden reflections in diffraction patterns due to double reflection. As reported in Makineni et al. [15], the orientation relationship between intermetallic compound $\mathrm{Co}_{3} \mathrm{Mo}\left(\mathrm{D0}_{19}\right)$ and Co-solid solution (FCC) can be presented as follows: [111]fcc//[0001]D0 $19 ;(101) \mathrm{fcc} / /(11-20) \mathrm{D}_{19}$. 

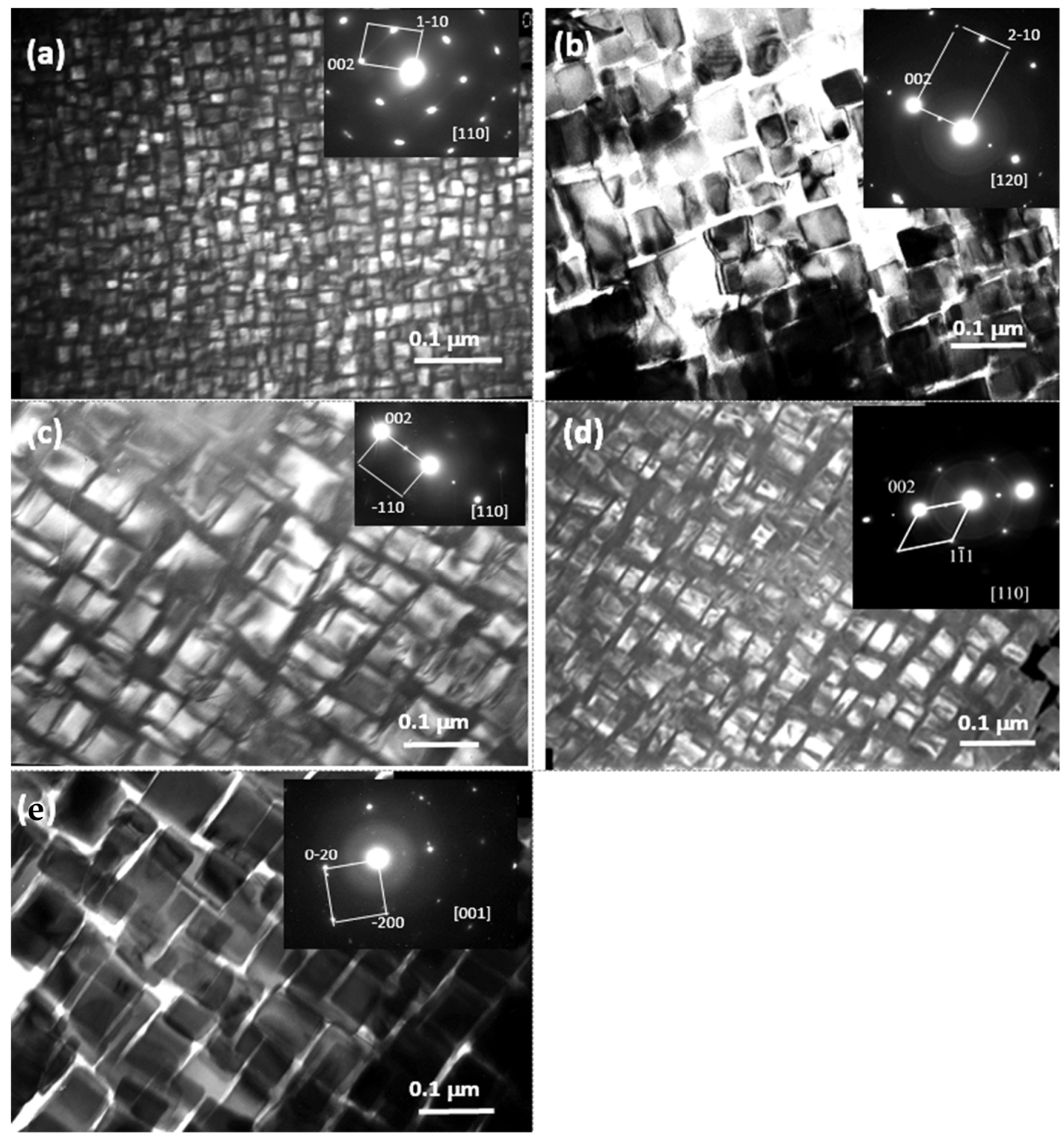

Figure 4. Structures of the $\gamma / \gamma^{\prime}$ phases in the studied alloys, TEM images: (a) Co-10Al-2Nb-5Mo; (b) Co-10Al-3Nb-7Mo; (c) $\mathrm{Co}-10 \mathrm{Al}-4 \mathrm{Nb}-3 \mathrm{Mo}$; (d) Co-10Al-9Nb-7Mo; (e) Co-10Al-5Nb-5Mo.

According to this orientation relationship, the transition matrixes between these two phases can be calculated as follows:

$$
\left(\begin{array}{c}
\mathrm{u} \\
\mathrm{v} \\
\mathrm{w}
\end{array}\right)_{\mathrm{D} 019}=\left(\begin{array}{ccc}
0 & \overline{1} & 1 \\
1 & \overline{1} & 1 \\
1 & 0 & 1
\end{array}\right) \cdot\left(\begin{array}{c}
\mathrm{u} \\
\mathrm{v} \\
\mathrm{w}
\end{array}\right)_{\mathrm{fcc}},\left(\begin{array}{c}
\mathrm{h} \\
\mathrm{k} \\
1
\end{array}\right)_{\mathrm{fcc}}=\left(\begin{array}{ccc}
0 & 1 & 1 \\
\overline{1} & \overline{1} & 1 \\
1 & 0 & 1
\end{array}\right) \cdot\left(\begin{array}{c}
\mathrm{h} \\
\mathrm{k} \\
1
\end{array}\right)_{\mathrm{D} 019}
$$

Figure $5 \mathrm{a}-\mathrm{c}$ presents the microstructure of the intermetallic compound $\mathrm{Co}_{3} \mathrm{Mo}$. The SAED pattern was indexed with transition matrixes between the FCC and $\mathrm{D}_{19}$ phases. Figure 5 shows the TEM images of the structure of the intermetallic precipitations in the $\mathrm{Co}-10 \mathrm{Al}-5 \mathrm{Nb}-5 \mathrm{Mo}$ and $\mathrm{Co}-10 \mathrm{Al}-4 \mathrm{Nb}-3 \mathrm{Mo}$ alloys. As can be seen in Figure 6, the precipitations had a needle shape. The reflex positions and their intensity in Selected area (electron) diffraction (SAED) pattern of the $\mathrm{Co}-10 \mathrm{Al}-5 \mathrm{Nb}-5 \mathrm{Mo}$ and $\mathrm{Co}-10 \mathrm{Al}-4 \mathrm{Nb}-3 \mathrm{Mo}$ alloys corresponded to the $\mathrm{Co}_{2} \mathrm{Nb}$ Laves phase (C14) (Figure 6). 

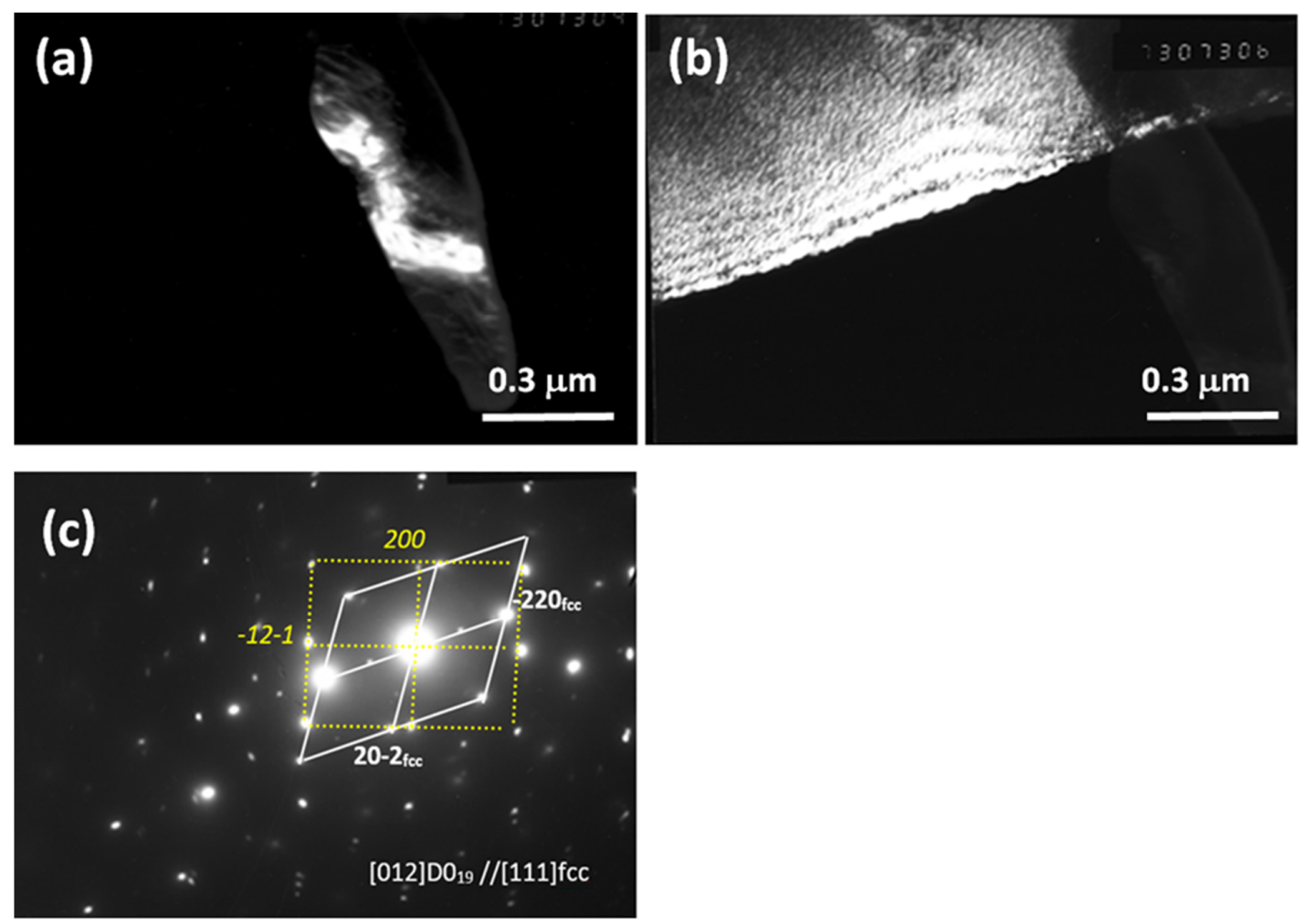

Figure 5. Structures of the Co-10Al-5Mo alloy, TEM images: (a) $\mathrm{Co}_{3} \mathrm{Mo}, \mathrm{D}_{19}$, the dark-field image taken with the (-12-1) $\mathrm{Co}_{3} \mathrm{Mo}$ reflex; (b) the dark-field image taken with (2-20)fcc (Co-solid solution); (c) SAED pattern to (a,b).
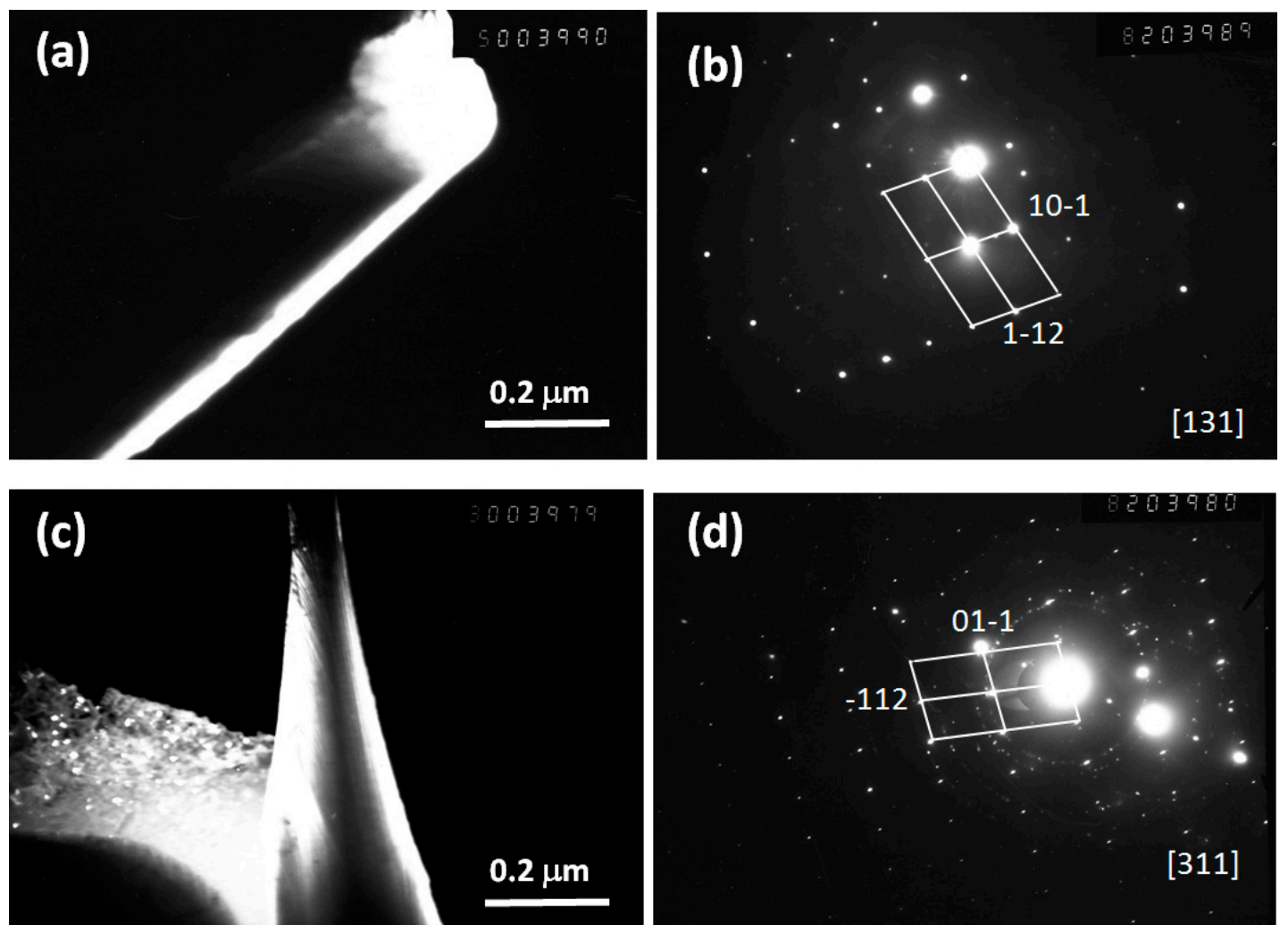

Figure 6. Structures of the intermetallic precipitations in the studied alloys, TEM images: (a) Co-10Al-5Nb-5Mo, the dark-field image taken with (0-13) $\mathrm{Co}_{2} \mathrm{Nb}$; (b) SAED pattern to (a); (c) Co-10Al-4Nb-3Mo, the dark-field image taken with (1-1-2) $\mathrm{Co}_{2} \mathrm{Nb}$; (d) SAED pattern to (c). 


\section{Conclusions}

The results of the experimental study of the phase transitions in the alloys of the $\mathrm{Co}-\mathrm{Al}-\mathrm{Nb}-\mathrm{Mo}$ system are presented. The obtained results were compared with the results for alloys of the binary $\mathrm{Co}-\mathrm{Al}$ and ternary $\mathrm{Co}-\mathrm{Al}-\mathrm{Nb}$, and $\mathrm{Co}-\mathrm{Al}-\mathrm{Mo}$ systems. The need for additions of the fourth component (niobium or molybdenum) for the formation of an ordered gamma prime phase $\left(\gamma^{\prime}\right.$-phase, $\left.\mathrm{L}_{2}\right)$ was shown.

The precipitations of the intermetallic compound $\mathrm{Co}_{2} \mathrm{Nb}$ (Laves phase, $\mathrm{HCP}$ ) were observed in the studied alloys of the $\mathrm{Co}-\mathrm{Al}-\mathrm{Nb}$ and $\mathrm{Co}-\mathrm{Al}-\mathrm{Nb}-\mathrm{Mo}$ systems.

Formation of the intermetallic phase with $\mathrm{L}_{2}$ structure was found in a range of alloys with 10 at. $\% \mathrm{Al}$ and $2-9$ at. $\% \mathrm{Nb}, 3-7$ at. \% Mo.

Author Contributions: D.D.: Conceptualization, Methodology, Investigation, Writing original manuscript. N.K.: Conceptualization, Draft revision, writing assistance. N.V.: TEM study. N.P.: Investigation. I.E.: Investigation. All authors have read and agreed to the published version of the manuscript.

Funding: This work was founded by the Russian Foundation for Basic Research (RFBR), project No. 20-33-70221 and Russian State program of Institute of Metal Physics “Additivity" № 121102900049-1.

Institutional Review Board Statement: Not applicable.

Informed Consent Statement: Not applicable.

Data Availability Statement: Data are available by request.

Conflicts of Interest: The authors declare no conflict of interest. The funders had no role in the design of the study; in the collection, analyses, or interpretation of data; in the writing of the manuscript, or in the decision to publish the results.

\section{References}

1. Zhu, L.; Wei, C.; Qi, H.; Jiang, L.; Jin, Z.; Zhao, J.C. Experimental investigation of phase equilibria in the Co-rich part of the Co-Al-X (X = W, Mo, Nb, Ni, Ta) ternary systems using diffusion multiples. J. Alloys Compd. 2017, 691, 110-118. [CrossRef]

2. Makineni, S.K.; Nithin, B.; Chattopadhyay, K. A new tungsten-free $\gamma-\gamma^{\prime}$ Co-Al-Mo-Nb-based superalloy. Scr. Mater. 2015, 98, 36-39. [CrossRef]

3. Tomaszewska, A.; Mikuszewski, T.; Moskal, G.; Migas, D. Primary microstructure, microsegregation and precipitates characterization of an as-cast new type $\gamma-\gamma^{\prime}$ Co-Al-Mo-Nb cobalt-based superalloy. J. Alloys Compd. 2018, 750, 741-749. [CrossRef]

4. Shaipov, R.K.; Kerimov, E.Y.; Slyusarenko, E.M. Isothermal Section of the Phase Diagram of the Co-Nb-Mo Ternary System at 1375 K. Mosc. Univ. Chem. Bull. 2015, 70, 183-189. [CrossRef]

5. Dovbenko, O.; Stein, F; Palm, M.; Prymak, O. Experimental determination of the ternary Co-Al-Nb phase diagram. Intermetallics 2010, 18, 2191-2207. [CrossRef]

6. Raghavan, V. Al-Co-Nb (Aluminum-Cobalt-Niobium). J. Phase Equilibria 2012, 33, 472-473. [CrossRef]

7. He CStein, F.; Palm, M. Thermodynamic description of the systems $\mathrm{Co}-\mathrm{Nb}, \mathrm{Al}-\mathrm{Nb}$ and $\mathrm{Co}-\mathrm{Al}-\mathrm{Nb}$. J. Alloys Compd. 2015, 637, 361-375. [CrossRef]

8. Saunders, N. The AI-Mo System (Aluminum-Molybdenum). J. Phase Equilibria 1997, 18, 370-378. [CrossRef]

9. Davydov, A.; Kattner, U.R. Thermodynamic Assessment of the Co-Mo System. J. Phase Equilibria 1999, 20, 5-16. [CrossRef]

10. Okamoto, H. Co-Nb (Cobalt-Niobium). J. Phase Equilibria 2010, 31, 94-95. [CrossRef]

11. McAlieter, A.J. The Al-Co (Aluminum-Cobalt) System. Bull. Alloy Phase Diagr. 1989, 10, 646-650.

12. Brewer, L.; Lamoreaux, R.H. The Mo-Nb phase diagram. In Compendium of Phase Diagram Data, Air Force Materials Laboratory; Rudy, E., Ed.; Rep. No. AFML-TR-65-2, Part V; Wright-Patterson AFB: Montgomery, OH, USA, 1969.

13. da Silva, A.A.A.P.; Coelho, G.C.; Nunes, C.A.; Fiorani, J.M.; David, N.; Vilasi, M. Nb-Al Binary System: Reevaluation of the Solubility Limits of the $(\mathrm{Nb}), \mathrm{Nb}_{3} \mathrm{Al}, \mathrm{Nb}_{2} \mathrm{Al}$ and $\mathrm{NbAl}_{3}$ Phases at High Temperatures. Mater. Res. 2019, 22, e20190305. [CrossRef]

14. Lyakishev, N.P. (Ed.) Phase Diagrams of Binary Metallic Systems; Mechanical Engineering: Moscow, Russia, 1996-2000; ISBN 5-217-02688-X.

15. Makineni, S.K.; Nithin, B.; Palanisamy, D.; Chattopadhyay, K. Phase evolution and crystallography of precipitates during decomposition of new "tungsten-free" $\mathrm{Co}(\mathrm{Ni})-\mathrm{Mo}-\mathrm{Al}-\mathrm{Nb} \gamma / \gamma^{\prime}$ superalloys at elevated temperatures. J. Mater. Sci. 2016, 51, 7843-7860. [CrossRef]

16. Damian Migas, D.; Moskal, G.; Maciag, T. Thermal analysis of W-free Co-(Ni)-Al-Mo-Nb superalloys. J. Therm. Anal. Calorim. 2020, 142, 149-156. [CrossRef]

17. Davydov, D.I.; Kazantseva, N.V.; Ezhov, I.V.; Gaviko, V.S.; Popov, N.A. Study of structural phase transformations in cobalt heat resistant alloys. AIP Conf. Proc. 2020, 2310, 020070. [CrossRef] 
18. Davydov, D.; Kazantseva, N.; Ezhov, I.; Popova, E. Effect of alloying on the $\gamma-\gamma^{\prime}$ microstructure of W-free Co-based superalloys. Mater. Today Proc. 2021, 38, 1971-1973. [CrossRef]

19. Kazantseva, N.V.; Stepanova, N.N.; Vinogradova, N.I.; Demakov, S.L.; Yurovskikh, A.S.; Davydov, D.I.; Shishkin, D.A.; Rigmant, M.B.; Romanov, E.P. Study of the martensitic transformation in the Co-9 at \% Al alloy. Phys. Met. Metallogr. 2016, 117, 42-48. [CrossRef]

20. Grüner, D.; Stein, F.; Palm, M.; Konrad, J.; Ormeci, A.; Schnelle, W.; Grin, Y.; Kreiner, G. Preparation, phase stability and structure of the C36 Laves phase $\mathrm{Nb}_{1-\mathrm{x}} \mathrm{Co}_{2+x}$. Z. Krist.-Cryst. Mater. 2006, 221, 319-333. [CrossRef]

21. Aufrecht, J.; Leineweber, A.; Duppel, V.; Mittemeijer, E.J. Layer-stacking irregularities in C36-type $\mathrm{Nb}-\mathrm{Cr}$ and Ti-Cr Laves phases and their relation with polytypic phase transformations. Philos. Mag. 2010, 90, 3149-3175. [CrossRef]

22. Palm, M.; He, C.; Dovbenko, O.; Stein, F.; Schuster, J.C. Liquidus Projection and Reaction Scheme of the Co-Al-Nb System. J. Phase Equilibria Diffus. 2012, 33, 210-221. [CrossRef]

23. Stein, F.; Leineweber, A. Laves phases: A review of their functional and structural applications and an improved fundamental understanding of stability and properties. J. Mater. Sci. 2021, 56, 5321-5427. [CrossRef]

24. $\mathrm{Co}_{3} \mathrm{Mo}$. Available online: https://materialsproject.org/materials/mp-1139/ (accessed on 26 October 2021).

25. $\mathrm{Co}_{2} \mathrm{Nb}$. Available online: https://materialsproject.org/materials/Co2Nb/ (accessed on 26 October 2021). 